\title{
Pulmonary Fungal Co-Infection Prevalence among Iranian Patients with Pulmonary Tuberculosis: A Systematic Review and Meta-Analysis
}

(Kelaziman Jangkitan Bersama Kulat Pulmonari dalam Kalangan Pesakit Iran dengan Batuk Kering Pulmonari: Suatu Ulasan Sistematik dan Metaanalisis)

\author{
Hamed MorTaZaVi, MeHran GHaZALibina, SHAMSEddin Mansouri, \\ AZAD KHALEDI* \& EHSAN SABURI
}

\begin{abstract}
Tuberculosis (TB) is further aggravated if it is accompanied with fungal co-infection. This study aimed to evaluate the prevalence of pulmonary fungal co-infection among Iranian patients with pulmonary TB using a systematic review and meta-analysis. The present study was a review of cross-sectional studies on the prevalence of pulmonary fungal co-colonization among Iranian patients with pulmonary TB with regard to the PRISMA Protocol. To this end, the articles published online in English and Persian were searched on the main databases and gateways such as Google Scholar, Science Direct, Web of Science, MEDLINE, PubMed, SCOPUS, Cochrane Library, Magiran, Irandoc, and Scientific Information Databases. The reviews of the literatures published online from 2000 to the end of 2018 were included in the study. The keywords used for searching through the databases were pulmonary fungal co-infection with pulmonary $T B$, pulmonary mycosis co-infection with pulmonary TB, pulmonary fungal colonization/agents with pulmonary TB, AND Iran. Finally, the collected data were analyzed by Comprehensive Meta-Analysis software. The analyses showed that the prevalence of fungal co-infection among patients with pulmonary TB varied from 12.3-68.8\%, and that the combined prevalence of fungal co-infection among patients with pulmonary $T B$ was $17.4 \%$. Amongst the fungi involved in co-infection with TB, Candida spp. was the most predominant with the prevalence of $6.9 \%$, followed by Aspergillus spp. (3.2\%). Moreover, the highest prevalence of Aspergillus spp. was observed for Aspergillus fumigatus (1.6\%). The most frequent Candida spp. was Candida albicans with a frequency of $6 \%$. The findings showed that the combined prevalence of fungal co-infection among Iranian patients with pulmonary TB was high. In this regard, among the fungi involved in co-infection with $T B$, Candida spp. was the most frequent.
\end{abstract}

Keywords: Aspergillus spp.; Candida spp.; co-infection; pulmonary tuberculosis

ABSTRAK

Batuk kering (TB) menjadi bertambah teruk jika ia diiringi dengan jangkitan bersama kulat. Kajian ini bertujuan untuk menilai kelaziman jangkitan bersama kulat dalam kalangan pesakit Iran dengan TB pulmonari menggunakan ulasan sistematik dan metaanalisis. Kajian semasa ini adalah penyemakan semula kajian keratan lintang mengenai kelaziman pengkolonian bersama kulat dalam kalangan pesakit Iran dengan TB pulmonari berkaitan dengan protokol PRISMA. Sehingga kini, kertas yang diterbitkan secara atas talian dalam Bahasa Inggeris dan Parsi telah dicari di pangkalan data utama dan get laluan seperti Google Scholar, Science Direct, Web of Science, MEDLINE, PubMed, SCOPUS, Cochrane Library, Magiran, Irandoc serta Pangkalan Data Maklumat Saintifik. Ulasan daripada kajian kepustakawan yang diterbitkan secara atas talian dari tahun 2000 hingga akhir 2018 telah dimasukkan dalam kajian. Kata kunci yang digunakan untuk mencari melalui pangkalan data adalah jangkitan bersama kulat pulmonari dengan TB pulmonari, jangkitan bersama mikosis pulmonari dengan TB pulmonari, pengkolonian/agen kulat pulmonari dengan TB pulmonari DAN Iran. Akhirnya, data yang diperoleh dianalisis menggunakan perisian metaanalisis yang komprehensif. Analisis ini menunjukkan bahawa kelaziman jangkitan bersama kulat dalam kalangan pesakit dengan TB pulmonari berjulat antara 12.3-68.8\% dan gabungan kelaziman untuk jangkitan bersama kulat dalam kalangan pesakit dengan TB pulmonari adalah 17.4\%. Antara kulat yang terlibat dalam jangkitan bersama TB ialah Candida spp. - paling pradominan dengan kelaziman 6.9\%, diikuti oleh Aspergillus spp. (3.2\%). Selain itu, kelaziman tertinggi Aspergillus spp. telah diperhatikan pada Aspergillus fumigatus (1.6\%). Candida spp. yang paling kerap ditemui adalah Candida albicans dengan kekerapan 6\%. Hasil kajian menunjukkan bahawa kelaziman jangkitan bersama kulat dalam kalangan pesakit Iran dengan TB pulmonari adalah tinggi. Dalam hal ini, antara kulat yang terlibat dalam jangkitan bersama TB, Candida spp. adalah yang paling kerap.

Kata kunci: Aspergillus spp.; batuk kering pulmonari; Candida spp.; jangkitan bersama 


\section{INTRODUCTION}

Mycobacterium is a genus of Actinobacteria, which induce a variety of diseases in human beings. Moreover, tuberculosis (TB) complex species also cause serious diseases in human, including TВ (Mycobacterium TB) and leprosy (Mycobacterium leprae). Nontuberculous mycobacteria play a critical role in medical microbiology (Khaledi et al. 2017, 2016). In general, nontuberculous mycobacteria are nonpathogenic microorganisms; however, they sometimes induce infection in individuals with immune-compromised conditions (Akbari et al. 2015).

TB is a chronic disease with pulmonary and extrapulmonary forms (Amiri et al. 2018a). More than $85 \%$ of TB cases are pulmonary, and some are extra-pulmonary. TB infects one-third of the world population, and about two million people died annually from TB (Ashna et al. 2018). More than $95 \%$ of pulmonary forms of TB are reported in developing countries such as the Middle East, Latin America, Africa, and Asia (Amiri et al. 2018b).

To the best of our knowledge, the problem with the pulmonary form is infection with opportunistic fungi that do not cause infection in normal conditions; however, they can be problematic if susceptible hosts are present, making pulmonary more severe and posing difficulties in the treatment of TB (Richardson \& Lass-Flörl 2008). Opportunistic fungal infections are typically formed by non-pathogenic fungal agents in patients whose immune responses are damaged by various predisposing factors (Romani 2011). A large increase in the number of immunocompromised hosts leads to an increase in opportunistic fungal infections and subsequently enhances the morbidity and mortality rates (Garber 2001).

One of the main opportunist fungi is Candida spp., particularly C. albicans with the prevalence rate of $10-90 \%$. Many studies have reported the prevalence of pulmonary TB co-infection with Candidiasis to be about $15-35 \%$ (Naz \& Tariq 2004). The chronic nature of TB is further aggravated if it is accompanied with fungal co-infection. In this case, it remains undetectable and consequently untreated (Denning et al. 2011).

The co-occurrence of Candida species and TB has been documented long time ago (Longo et al. 1958). When accompanied with primary diseases such as TB, Candida infections may cause many complications in patients, especially in those with predisposing factors for fungal infections such as weak immune status and damaged lung tissues and TB-induced lesions (Rathod et al. 2012). Additionally, prolonged treatment with antibiotics and corticosteroids further expose these patients to fungal opportunistic infections.

Individuals sometimes suffer from pulmonary $\mathrm{TB}$ treated by antibiotics, which have complications such as progressive injury of lungs, persistent pulmonary symptoms, and chronic pulmonary mycosis (Denning et al. 2011b). Chronic pulmonary mycosis, in particular contamination with aspergillosis, is a remarkable differential diagnosis in patients with smear-negative TB. Amongst different Aspergillus spp., A. fumigatus is the most frequent (Kosmidis \& Denning 2015). The most important form of Aspergillus is chronic pulmonary aspergillosis (CPA) with or without aspergilloma (Denning 2009). In comparison to invasive aspergillosis, however, CPA occurs in individuals with immune deficiency, leading to a high mortality rate of about 10-30\% (Nam et al. 2010), systemic and respiratory symptoms, hemoptysis (Denning et al. 2003), weight loss, profound fatigue, and decreased lung function (Camuset et al. 2007).

Considering the critical role of fungal agents and their co-infection with TB and given that there is no comprehensive review in this regard, a systematic review and meta-analysis was carried out in the present study to determine the prevalence of pulmonary fungal co-infection among Iranian patients with pulmonary TB through summarizing the data collected from the published literature. We followed the Moose (Meta-Analyses and Systematic Reviews of Observational Studies) and the Preferred Items for Systematic Reviews and MetaAnalyses (PRISMA) guidelines to report the findings from this systematic review and meta-analysis (Stroup et al. 2000).

\section{MATERIALS AND METHODS}

\section{SEARCH STRATEGY}

The present study was a review of cross-sectional studies on the prevalence of pulmonary fungal co-infection among Iranian patients with pulmonary TB in accordance with the PRISMA directions (Stroup et al. 2000) (File 1). For this purpose, papers published in both national and international databases were surveyed. Articles published online in English and Persian from 2000 to the end of 2018 were selected from international (Google Scholar, PubMed, MEDLINE, SCOPUS, Cochrane Library, ScienceDirect, and Web of Science) and with similar strategies and related Persian keywords through national (SID, Magiran, and Irandoc) databases and gateways. Additionally, the reference lists of the articles were also checked for further studies.

The keywords used for searching the databases were pulmonary fungal co-infection with pulmonary tuberculosis, pulmonary mycosis co-infection with pulmonary tuberculosis, pulmonary fungal infections/ agents with pulmonary tuberculosis, AND Iran.

\section{INCLUSION AND EXCLUSION CRITERIA}

In this study, inclusion criteria were as follows: Observational studies reporting the prevalence of pulmonary fungal co-infection with pulmonary TB; crosssectional, full-text papers published from 2000 to the end of 2018 with relevant subject. On the other hand, those studies not addressing the research topic, getting published before 2000, commentaries, abstracts, case series, case reports, meeting reports, letters to editor, congress articles, 
editorials, literatures containing incoherent data reporting, articles reported in languages other than English or Persian, republished papers, literature reviews, meta-analysis, systematic and narrative reviews were excluded.

\section{SCREENING}

All the studies found in the aforementioned databases were entered into our prepared database in order for the copied papers to be eliminated. Then, the articles were screened by two reviewers (AM \& SM) at three levels (namely, title and abstract screening, topic screening, and full-text screening). At each level, the reviewers independently screened the papers, and their findings were merged upon their agreements. The inconsistencies were resolved by debate before finalizing the studies for the next screening step. The disagreements between the reviewers were discussed and resolved by agreement; however, when no agreement was reached, a third reviewer made the final decision. Finally, the articles were assessed in terms of eligibility for final selection.

\section{QUALITY OF STUDIES}

The quality of the methods in the concerned studies was assessed using the criteria declared in Critical Appraisal Skills Programmed checklists (www.casp-UK). A set of key questions were considered for each study. If relevant information was explicitly stated, the relevant question would be answered as 'Yes'. If there was any kind of doubt or the information was not explicitly described in the paper, the question would be responded as 'No' or 'Can't tell'. The overall rating of the studies ranged from 'strong' and 'intermediate' to 'weak' according to the number of questions marked as 'Yes'(CASP 2006). At the end, the studies of low quality were removed from the present study.

\section{ASSESSING THE RISK OF BIAS}

In the concerned articles, the study design, methods, context, results, data analyses, and interpretations were examined for quality evaluation. Incoherent reviews of literature were excluded from the present investigation. Furthermore, the disagreements on the quality evaluation were resolved by debates between the two raters or the third reviewer (Auguste et al. 2017).

\section{DATA EXTRACTION}

The two reviewers independently extracted the necessary data from the selected articles. The concerned information encompassed first author, year of study, year of publication, sample size, genus, age, location, co-infection, and fungi species. The disagreement between the reviewers was resolved through discussion.

\section{STATISTICAL ANALYSIS}

The analysis was performed by Comprehensive MetaAnalysis Software Version 2.0 (Biostat, Englewood,
NJ). The prevalence rate was reported at $95 \%$ confidence intervals (CIs).

\section{RESULTS}

\section{STUDY SELECTION}

As shown in Figure 1, 162 records were detected from a systematic literature search of different electronic databases and gateways, of which 51 copied records were removed, and 111 records were screened. Out of these 111 articles, 61 papers were excluded because of their irrelevant topics, titles, and review articles, and 50 full-text articles were further evaluated for eligibility. Regarding the eligibility criterion, 46 papers were excluded after a full text assessment ( 25 articles for lack of required data and 21 articles for not describing the prevalence rates). Finally, the studies $(n=4)$ were included in the quantitative synthesis (meta-analysis).

\section{FEATURES OF THE SELECTED STUDIES}

As presented in Table 1, the patients with positive pulmonary TB were 700 persons. The age of the patients ranged from 10 to 91 years (with the mean age of 48 years).

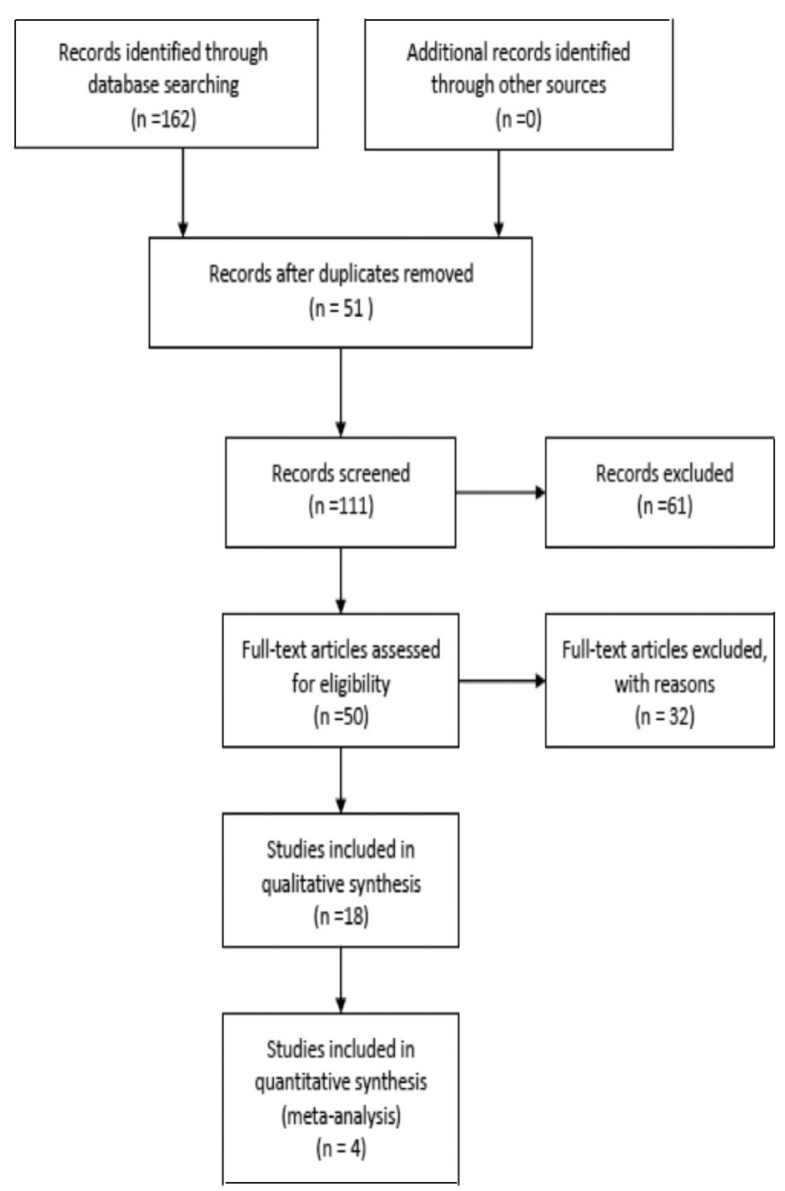

FIGURE 1. This Flow diagram shows the selection process of included studies 
The type of clinical samples in most cases was sputum followed by Bronchoalveolar lavage (BAL) and serum.

\section{FINDINGS OF THE COMBINED PREVALENCE}

According to the findings listed in Table 2 and Figure 2, the prevalence of fungal co-infection among patients with pulmonary ТВ varied from $12.3 \%$ to $68.8 \%$. Table 2 and Figure 3 show that the combined prevalence of fungal co-infection among Iranian patients with pulmonary $\mathrm{TB}$ was $17.4 \%$ (95\% CI: 7.3-36.1, $\mathrm{Q}=3$ and $\mathrm{Z}=3.09)$. Table 3 indicates that, amongst fungi involved in co-infection with TB, Candida spp. was the most predominant with the prevalence rate of $6.9 \%(95 \%$ CI: $5.3-9, \mathrm{P}=0.00, \mathrm{t}=0.4$, $\mathrm{Z}=17.6$ ), followed by Aspergillus spp. with the prevalence rate of $3.2 \%(95 \% \mathrm{CI}: 2.4-4.2, \mathrm{P}=0.00, \mathrm{t}=0.5, \mathrm{Z}=23.2)$. The most frequent Candida spp. was $C$. albicans with the frequency of $6 \%$ (95\% CI: 4.4-8.3). Moreover, the most frequent Aspergillus spp. was A. fumigatus with the prevalence rate of $1.6 \%(95 \%$ CI: $1.1-2.3)$. Other features of Candida and Aspergillus spp. are shown in Table 3.

The publication bias was checked using Funnel plot, and the results (Figure 3) showed no publication bias for the combined prevalence of co-infection and Candida spp.; however, publication bias was reported for the prevalence of Aspergillus spp. Considering possible asymmetrical data distribution in the selected studies, the Egger's linear regression was used to further examine the publication bias; however, the results of the Egger's linear regression also showed no publication bias $(P=0.6)$ (Table 1$)$.

In all the studies, bacterial staining such as ZiehlNeelsen and fluorochrome and mycological examination $(10 \% \mathrm{KOH}+$ Calcofluor White staining by fluorescent microscopy and fungal culture on Sabouraud dextrose agar, Czapek, and CHROMagar) were used for the detection and identification of infectious agents.

\section{DISCUSSION}

In the present review, the prevalence of fungal co-infection among Iranian patients with pulmonary TB varied from $12.3 \%$ to $68.8 \%$. The combined prevalence of fungal co-infection was $17.4 \%$ among Iranian TB patients. Our findings are in line with those of Baradkar et al. (2009), Khanna et al. (1977), and Naz and Tariq (2004), as they reported the high prevalence of fungal co-infection with TB; however, the results of the study by Latha et al. (2011) reported a lower prevalence rate. The inconsistency might be caused by variations in the geographical dissemination, genetic features of patients, occupation of patients, sample size, duration of anti-TB consumption by patients, and methods used for detection (Astekar et al. 2016).

According to the results derived from the present study regarding the fungi involved in co-infection with TB, Candida spp. was the most frequent with the prevalence rate of $6.9 \%$. Moreover, the most leading Candida spp. was $C$. albicans with the frequency of $6 \%$. The results of this study are in line with the findings of the studies conducted by Kali et al. (2013) and Phukan et al. (2000). Similarly, they reported C. albicans as the most common fungus associated with infections in patients with immunecompromised conditions such as TB. In addition, a study carried out by Naz and Tariq (2004) in Pakistan showed $15.2 \%$ co-infection of tuberculous patients admitted in hospital with Candida spp. In a similar study conducted in China showed $21.6 \%$ of fungal co-occurrence with Candida spp. among hospitalized patients with underlying primary pulmonary diseases (Liu et al. 2003).

C. albicans is present in hospital environments, air, inanimate surfaces, and even food substances. It is considered as the common yeast recovered from tuberculous patients and is responsible for producing severe secondary infections in these patients (Fontalvo et al. 2016). Nevertheless, the current findings are in contrast with those of Naz and Tariq (2004) who indicated C. tropicalis as the frequent species. The reason for this difference is likely to be the inclusion of AIDS positive patients in their study, where C. tropicalis more strongly attacked deep tissues of immunocompromised individuals compared to C. albicans (Meurman et al. 2007).

Many researchers have identified different Candida spp. as the most common fungal agents isolated from patients' mucus production with pulmonary TB (Kali et al. 2013). The reason is that the correlation between synergistic growth-promoting and $M . T B$ has also been empirically documented (Latha et al. 2011).

However, due to the fact that Candida spp. is present in the normal flora of $15-30 \%$ of individuals, the importance of infections caused by it is controversial and may contaminate sputum samples when sampling (ElEbiary et al. 1997). It should be noted that patients with TB have a deficiency in the function of immunological cells including monocytes, macrophages, and $\mathrm{T}$ cells, as well as chemotaxis that can predispose patients to opportunistic fungal infections (Dagenais \& Keller 2009). Due to the development of cavities after the healing of TB, aspergillosis can be placed in cavities after a long time and form aspergilloma (Smith \& Denning 2011). Among various underlying conditions, TB is the most important factor in the development of CPA (Ohba et al. 2012).

In the present study, the combined prevalence of Aspergillus spp. was $3.2 \%$. Among them, the highest prevalence of Aspergillus spp. was associated with A. fumigatus (1.6\%). Based on reports, A. fumigatus is the most frequent species involved in all pulmonary disorders (Kosmidis \& Denning 2015). In contrast to our study, in studies conducted by Ekkena et al. (2007), Kurhade et al. (2002), Njunda et al. (2012), and Osman et al. (2013), Aspergillus spp. was detected in 24\%, 15\%, 16.26\% and $42.9 \%$ of cases, respectively. The observed difference between these studies with the current study may be due to the number of reviewed studies and diverse geographical distribution (Osman et al. 2013).

Our findings are in accordance with results obtained by Kurhade et al. (2002) and Shahid et al. (2001) who described A. fumigatus as the predominant species in 

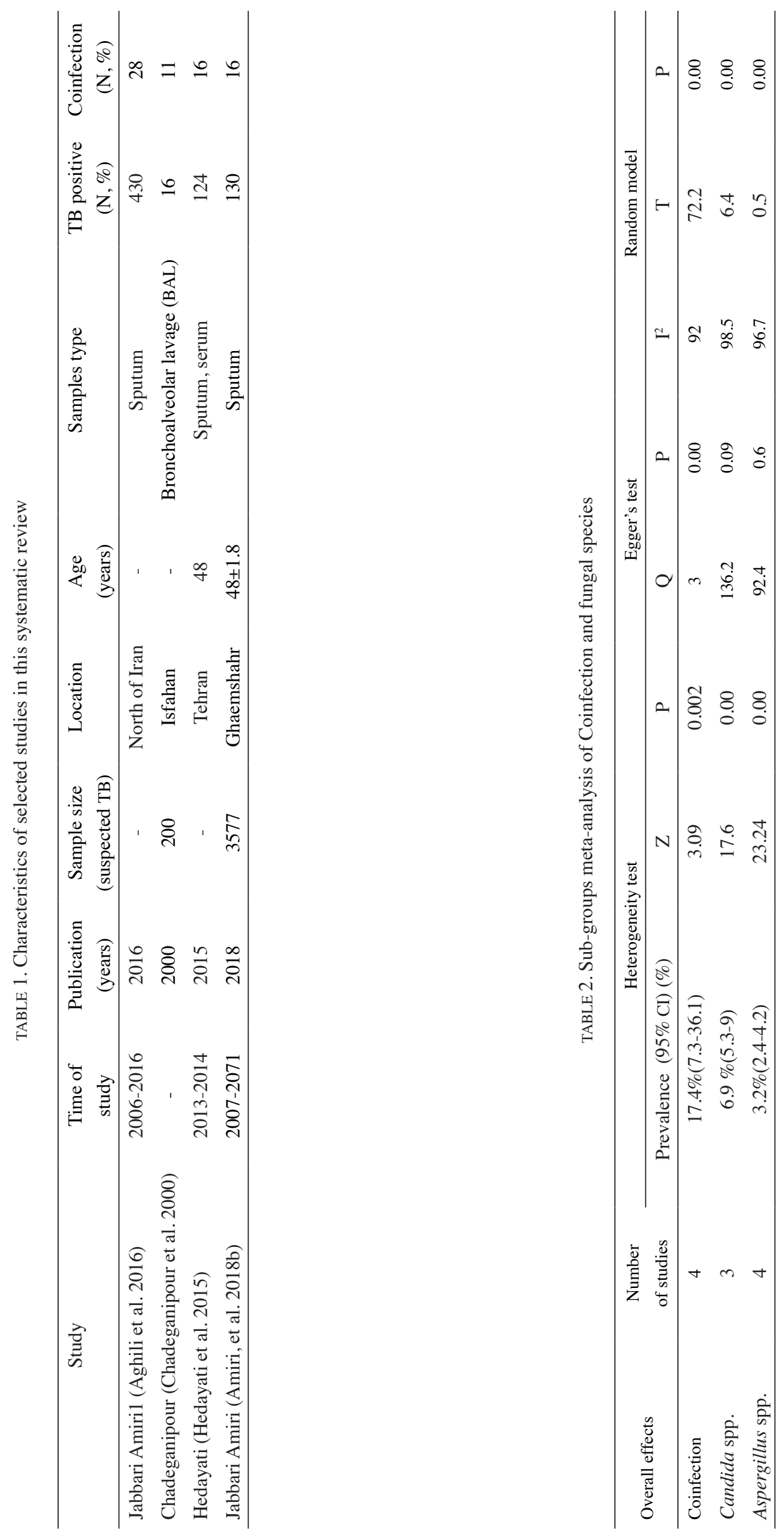


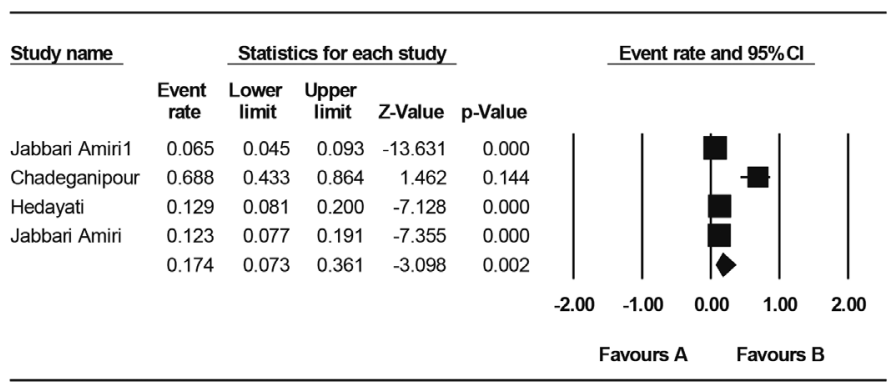

FIGURE 2. This figure shows the Forest plot of the meta-analysis of the prevalence of pulmonary fungal Coinfection among Iranian patients with pulmonary tuberculosis

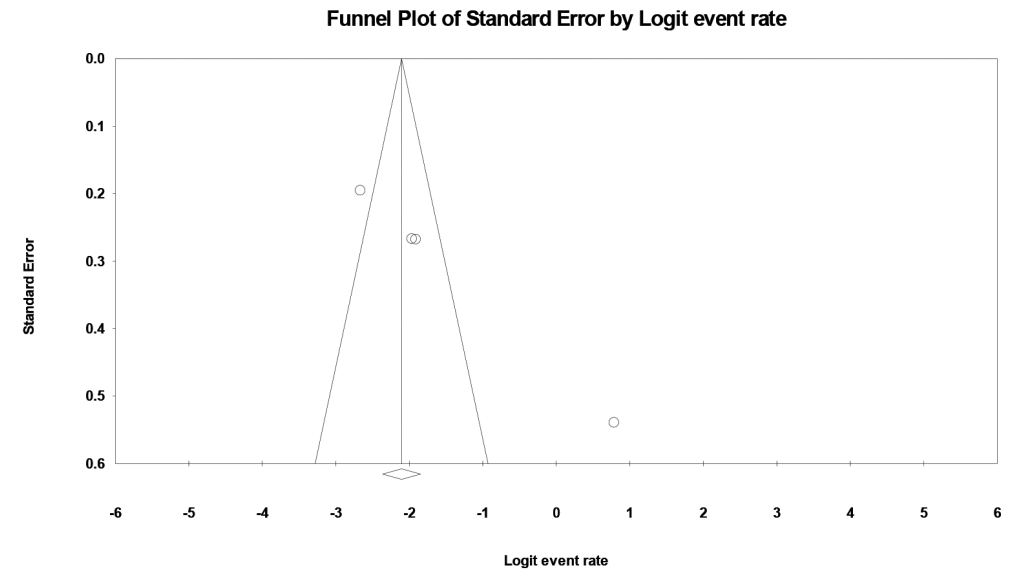

FIGURE 3. This shows the publication bias of the meta-analysis on the prevalence of pulmonary fungal Coinfection among Iranian patients with pulmonary tuberculosis

TABLE 3. Sub-groups analysis of Candida and Aspergillus species in this study

\begin{tabular}{|c|c|c|c|c|c|c|c|c|c|}
\hline \multicolumn{10}{|c|}{ Candida species } \\
\hline \multirow[b]{2}{*}{ Overall effects } & \multirow{2}{*}{$\begin{array}{l}\text { Number } \\
\text { of studies }\end{array}$} & \multicolumn{3}{|c|}{ Heterogeneity test } & \multicolumn{3}{|c|}{ Egger's test } & \multicolumn{2}{|c|}{ Random model } \\
\hline & & $\begin{array}{c}\text { Prevalence } \\
(95 \% \text { CI })(\%)\end{array}$ & $\mathrm{Z}$ & $\mathrm{P}$ & Q & $\mathrm{P}$ & $\mathrm{I}^{2}$ & $\mathrm{~T}$ & $\mathrm{P}$ \\
\hline Candida albicans & 3 & $6 \%(4.4-8.3)$ & 15.6 & 0.00 & 72.7 & 0.07 & 97.2 & 1 & 0.00 \\
\hline Candida krusei & 2 & $0.7 \%(0.3-1.8)$ & 9.9 & 0.00 & 0.59 & 0.00 & 0.00 & 0.00 & 0.00 \\
\hline Candida glabrata & 1 & $1 \%(0.3-3.9)$ & 6.4 & 1 & 0.00 & 0.00 & 0.00 & 0.00 & 0.00 \\
\hline Candida tropicalis & 1 & $1 \%(0.3-3.9)$ & 6.4 & 1 & 0.00 & 0.00 & 0.00 & 0.00 & 0.00 \\
\hline Candida pseudotropicalis & 1 & $1 \%(0.3-3.9)$ & 6.4 & 1 & 0.00 & 0.00 & 0.00 & 0.00 & 0.00 \\
\hline Non-Candida spp & 1 & $0.1 \%(0-0.03)$ & 13.5 & 0.00 & 0.00 & 0.00 & 0.00 & 0.00 & 0.00 \\
\hline \multicolumn{10}{|c|}{ Aspergillus species } \\
\hline Aspergillus flavus & 3 & $0.8 \%(0.4-1.4)$ & 15.8 & 0.00 & 17.9 & 0.48 & 88.8 & 1.05 & 0.00 \\
\hline Aspergillus fumigatus & 4 & $1.6 \%(1.1-2.3)$ & 20.6 & 0.00 & 58 & 0.6 & 94.8 & 0.4 & 0.00 \\
\hline Aspergillus niger & 3 & $0.1 \%(0.1-0.8)$ & 12.6 & 0.01 & 7.9 & 0.5 & 74.8 & 0.9 & 0.00 \\
\hline Aspergillus oryzae & 1 & $0.2 \%(0-1.6)$ & 6 & 1.00 & 0.00 & 0.00 & 0.00 & 0.00 & 0.00 \\
\hline
\end{tabular}

pulmonary TB. In contrast with our review, some studies (Biswas et al. 2010; Sivasankari et al. 2014) showed $A$. flavus and $A$. niger as the most common species in the Aspergillus genus. Moreover, in the present study, A. flavus and $A$. niger were reported to be low with the prevalence of $0.8 \%$ and $0.1 \%$, respectively. In contrary to our findings, the frequency of $A$. flavus in the study conducted by Shahid and Malik (2002) was obtained as high as $30 \%$. The increased prevalence of opportunistic fungal colonization is attributed to the weakness of the immune system in TB patients and the use of anti-TB drugs which provoke the growth of the fungus flora and thus aggravate the course of underlying diseases in the lung tissues (Naz \& Tariq 2004). 
In regions with a high occurrence of $\mathrm{TB}$, criteria for identifying both CPA and TB are highly identical, which make it impossible to distinct between the two microorganisms without serological tests for Aspergillus antigens, even if the culture of samples (sputum) is positive for A. fumigatus (Denning et al. 2011).

Despite that the patients completed the course of treatment for TB; secondary fungal infections had persistence of pulmonary symptoms. Therefore, suitable measures should be taken for patients in endemic areas for the potential of co-infection so that it can be identified and treated promptly (Mathavi et al. 2014).

Furthermore, all fungi detected in clinical specimens from patients, especially immune-compromised patients and those suffering from pulmonary carefully examined and evaluated by physicians regarding their clinical significance (Chadeganipour et al. 2000).

Due to the importance of $\mathrm{TB}$, attention should be paid more to the co-infection of TB with opportunistic fungi. In addition, because of comparable clinical signs of TB and pulmonary fungal co-infection, for cases in which the direct smear and culture of samples are negative for $\mathrm{TB}$, specimens must be evaluated for opportunistic fungi.

This review has several strengths. Accordingly, we performed a comprehensive study through searching in several databases based on the available standard protocol. To this end, we used two independent reviewers who searched for relevant studies and resolved any disagreements via discussion. Moreover, we used subgroups analysis for heterogeneity reduction.

However, the present study has also some limitations. First of all, we did not have access to all studies conducted in this field, related unpublished works, and literatures reported in languages other than English or Persian. Furthermore, we completed meta-analysis only on data obtainable in databases and gateways and did not contact the authors of the selected studies to achieve more information when further clarification required. Finally, we conducted this review with only four selected studies.

\section{CONCLUSION}

In general, based on our results, the combined prevalence of fungal co-infection is high among Iranian patients with pulmonary TB. Moreover, our results showed Candida spp. to be the most prevalent among fungi complicated in co-infection with TB. It is suggested to further investigate factors affecting fungal co-infection with pulmonary $\mathrm{TB}$ as well as complications resulting from the misdiagnosis of co-infection.

\section{ACKNOWLEDGEMENTS}

We would like to express our sincere thanks to our colleagues for collaboration in this work.

\section{REFERENCES}

Aghili, S.R., Shokohi, T., Hedayati, M.T.,Abastabar, M., Aliyali, M. \& Hasanpour, H. 2016. Invasive forms of Candida and Aspergillus in sputum samples of pulmonary tuberculosis patients attending the tuberculosis reference laboratory in Ghaemshahr, Northern Iran: An analysis of samples collected during the past 10 years. International Journal of Mycobacteriology 5: S179-S180.

Akbari, H., Khaledi, A., Nasr, R. \& Ghazvini, K. 2015. Epidemiology of nontuberculosis mycobacteria (NTMs), in drinking water distribution systems. International Journal of Analytical, Pharmaceutical and Biomedical Sciences 4(3).

Amiri, M.J., Karami, P., Chichaklu, A.H., Jangan, E.H., Amiri, M.J., Owrang, M., Farrokhy, F. \& Khaledi, A. 2018. Identification and isolation of Mycobacterium tuberculosis from Iranian patients with recurrent TB using different staining methods. Journal of Research in Medical and Dental Science 6(2): 409-414.

Amiri, M.R.J., Siami, R.\& Khaledi,A. 2018b. Tuberculosis status and coinfection of pulmonary fungal infections in patients referred to reference laboratory of health centers Ghaemshahr City during 2007-2017. Ethiopian Journal of Health Sciences 28(6): 683-690

Ashna, H., Kaffash, A., Khaledi, A. \& Ghazvini, K. 2018. Mutations of rpob gene associated with Rifampin resistance among Mycobacterium Tuberculosis isolated in Tuberculosis Regional Reference Laboratory in Northeast of Iran during 2015-2016. Ethiopian Journal of Health Sciences 28(3): 299-304.

Astekar, M., Bhatiya, P.S. \& Sowmya, G. 2016. Prevalence and characterization of opportunistic candidal infections among patients with pulmonary tuberculosis. Journal of Oral and Maxillofacial Pathology 20(2): 183-189.

Auguste, P., Tsertsvadze,A., Pink, J., McCarthy, N., Sutcliffe, P. \& Clarke, A. 2017. Comparing interferon-gamma release assays with tuberculin skin test for identifying latent tuberculosis infection that progresses to active tuberculosis: Systematic review and meta-analysis. BMC Infectious Diseases 17(1): 200.

Baradkar, V., Mathur, M., Wanjari, K. \& Kumar, S. 2009. Candida in pulmonary tuberculosis. Bombay Hospital Journal 51: 52-53.

Biswas, D., Agarwal, S., Sindhwani, G. \& Rawat, J. 2010. Fungal colonization in patients with chronic respiratory diseases from Himalayan region of India. Annals of Clinical Microbiology and Antimicrobials 9(1): 28.

Camuset, J., Nunes, H., Dombret, M.-C., Bergeron, A., Henno, P., Philippe, B., Dauriat, G., Mangiapan, G., Rabbat, A. \& Cadranel, J. 2007. Treatment of chronic pulmonary aspergillosis by voriconazole in nonimmunocompromised patients. Chest 131(5): 1435-1441.

CASP. 2006. 10 questions to help you make sense of qualitative research.

Chadeganipour, M., Shadzi, S., Dehghan, P. \& Bijary, J. 2000. The incidence of opportunistic fungi in patients suspected of tuberculosis. Mycoses 43(7-8): 269-272.

Dagenais, T.R. \& Keller, N.P. 2009. Pathogenesis of Aspergillus fumigatus in invasive aspergillosis. Clinical Microbiology Reviews 22(3): 447-465.

Denning, D.W. 2009. Chronic Aspergillosis Aspergillus fumigatus and Aspergillosis. Washington: American Society of Microbiology. pp. 319-331. 
Denning, D.W., Park, S., Lass-Florl, C., Fraczek, M.G., Kirwan, M., Gore, R., Smith, J., Bueid, A., Moore, C.B., Bowyer, P. \& Perlin, D.S. 2011a. High-frequency triazole resistance found in nonculturable Aspergillus fumigatus from lungs of patients with chronic fungal disease. Clinical Infectious Diseases 52(9): 1123-1129.

Denning, D.W., Pleuvry, A. \& Cole, D.C. 2011b. Global burden of chronic pulmonary aspergillosis as a sequel to pulmonary tuberculosis. Bulletin of the World Health Organization 89: 864-872.

Denning, D.W., Riniotis, K., Dobrashian, R. \& Sambatakou, H. 2003. Chronic cavitary and fibrosing pulmonary and pleural aspergillosis: Case series, proposed nomenclature change, and review.Clinical Infectious Diseases 37(Supplement_3): S265-S280.

Ekenna, O., Uba, A., Chikwem, J., Mambula, S., Aliyu, M. \& Mohammed, I. 2007. Relevance of moldy fungi as agents of chronic lower respiratory tract infection in patients seen in Maiduguri, Nigeria. West African Journal of Medicine 26(2): 117-120.

El-Ebiary, M., Torres, A., Fabregas, N., de la Bellacasa, J.P., Gonzalez, J., Ramirez, J., del Baño, D., Hernández, C. \& Jiménez de Anta, M.T. 1997. Significance of the isolation of Candida species from respiratory samples in critically ill, nonneutropenic patients: an immediate postmortem histologic study. American Journal of Respiratory and Critical Care Medicine 156(2): 583-590.

Fontalvo, D.M., Jiménez Borré, G., Gómez Camargo, D., Chalavé Jiménez, N., Bellido Rodríguez, J., Cuadrado Cano, B. \& Navarro Gómez, S. 2016. Tuberculosis and fungal coinfection present in a previously healthy patient. Colombia Médica 47(2): 105-108.

Garber, G. 2001. An overview of fungal infections. Drugs 61(1): 1-12.

Hedayati, M., Azimi, Y., Droudinia, A., Mousavi, B., Khalilian, A., Hedayati, N. \& Denning, D.W. 2015. Prevalence of chronic pulmonary aspergillosis in patients with tuberculosis from Iran. European Journal of Clinical Microbiology \& Infectious Diseases 34(9): 1759-1765.

Kali, A., Charles, M.P., Noyal, M.J., Sivaraman, U., Kumar, S. \& Easow, J.M. 2013. Prevalence of Candida co-infection in patients with pulmonary tuberculosis. The Australasian Medical Journal 6(8): 387-391.

Khaledi, A., Bahador, A., Esmaeili, D. \& Ghazvini, K. 2017. Prevalence of nontuberculous mycobacteria (NTM) in Iranian clinical specimens: Systematic review and meta-analysis. Journal of Medical Bacteriology 5(3-4): 29-40.

Khaledi, A., Bahador, A., Esmaeili, D., Tafazoli, A., Ghazvini, K. \& Mansury, D. 2016. Prevalence of nontuberculous mycobacteria isolated from environmental samples in Iran: A meta-analysis. Journal of Research in Medical Sciences: The Official Journal of Isfahan University of Medical Sciences 21: 58

Khanna, B., Nath, P. \& Ansari, A. 1977. A study of mycotic flora of respiratory tract in pulmonary tuberculosis. Ind. J. Tub. XXIV(4): 159-162.

Kosmidis, C. \& Denning, D.W. 2015. The clinical spectrum of pulmonary aspergillosis. Thorax 70(3): 270-277.

Kurhade, A., Deshmukh, J., Fule, R., Chande, C. \& Akulwar, S. 2002. Mycological and serological study of pulmonary aspergillosis in central India. Indian Journal of Medical Microbiology 20(3): 141-144.
Latha, R., Sasikala, R., Muruganandam, N. \& Venkatesh Babu, R. 2011. Study on the shifting patterns of Non Candida albicans Candida in lower respiratory tract infections and evaluation of the CHROMagar in identification of the Candida species. J. Microbiol. Biotech. Res. 1(3): 113-119.

Liu, Z., Sheng, R., Li, X., Li, T. \& Wang, A. 2003. Nosocomial fungal infections, analysis of 149 cases. Zhonghua Yi Xue Za Zhi 83(5): 399-402.

Longo, L.B., Harbuck, A.B. \& Fleischmann, W. 1958. Coexistence of fungi and tubercle bacilli. Diseases of the Chest 33(4): 398-400.

Mathavi, S., Shankar, R., Kavitha, A., Sasikala, G. \& Priyadharsini, I. 2014. A study on prevalence of pulmonary candidiasis among tuberculosis patients and use of chromagar in identification of Candida species. Journal of Drug Delivery and Therapeutics 4(3): 118-121.

Meurman, J., Siikala, E., Richardson, M. \& Rautemaa, R. 2007. Non-Candida albicans Candida yeasts of the oral cavity. Communicating Current Research and Educational Topics and Trends in Applied Microbiology 1(1): 719-731.

Nam, H-S., Jeon, K., Um, S-W., Suh, G.Y., Chung, M.P., Kim, H., Kwon, O.J. \& Koh, W-J. 2010. Clinical characteristics and treatment outcomes of chronic necrotizing pulmonary aspergillosis: A review of 43 cases. International Journal of Infectious Diseases 14(6): e479-e482.

Naz, S.A. \& Tariq, P. 2004. A study of the trend in prevalence of opportunistic Candidal co-infections among patients of pulmonary tuberculosis. Pak. J. Bot. 36: 857-862.

Njunda, A.L., Ewang, A.A., Kamga, L.H.F., Nsagha, D.S., Assob, J.C.N., Ndah, D.A. \& Kwenti, T.E. 2012. Respiratory tract Aspergillosis in the sputum of patients suspected of tuberculosis in Fako division-Cameroon. Journal of Microbiology Research 2(4): 68-72.

Ohba, H., Miwa, S., Shirai, M., Kanai, M., Eifuku, T., Suda, T., Hayakawa, H. \& Chida, K. 2012. Clinical characteristics and prognosis of chronic pulmonary aspergillosis. Respiratory Medicine 106(5): 724-729.

Osman, N.M., Gomaa, A.A. \& Sayed, N.M. 2013. Microarray detection of fungal infection in pulmonary tuberculosis. Egyptian Journal of Chest Diseases and Tuberculosis 62(1): 151-157.

Phukan, A., Sarmabordoloi, J. \& Mahanta, J. 2000. Bronchopulmonary candidiasis in a tertiary referral hospital of Assam, India. Indian Journal of Medical Sciences 54(11): 491-494.

Rathod, V.S., Raut, J.S. \& Mohan Karuppayil, S. 2012. Antifungal drug susceptibility of Candida albicans isolates from pulmonary tuberculosis patients. Int. J. Pharm. Pharm. Sci. 4(Suppl 5): 323-326.

Richardson, M. \& Lass-Flörl, C. 2008. Changing epidemiology of systemic fungal infections. Clinical Microbiology and Infection 14: 5-24.

Romani, L. 2011. Immunity to fungal infections. Nature Reviews Immunology 11(4): 275-288.

Shahid, M. \& Malik, A. 2002. A comparative study of two culture media for the growth of pathogenic Aspergillus species: An aid to early diagnosis. Bio-Science Res. Bulletin 18: 65-70.

Shahid, M., Malik, A. \& Bhargava, R. 2001. Prevalence of aspergillosis in chronic lung diseases. Indian Journal of Medical Microbiology 19(4): 201-205.

Sivasankari, S., Senthamarai, S., Anitha, C., Apurba Sankar Sastry, S.B., Kumudhavathi, M. \& Amshavathani, S. 2014. Prevalence of invasive aspergillosis among (PTB) patients 
in Kanchipuram, India. Journal of Clinical and Diagnostic Research 8(3): 22-23.

Smith, N. \& Denning, D. 2011. Underlying conditions in chronic pulmonary aspergillosis including simple aspergilloma. European Respiratory Journal 37(4): 865-872.

Stroup, D.F., Berlin, J.A., Morton, S.C., Olkin, I., Williamson, G.D., Rennie, D., Thacker, S. B. 2000. Meta-analysis of observational studies in epidemiology: A proposal for reporting. JAMA 283(15): 2008-2012.

\section{Hamed Mortazavi}

Geriatric Care Research Center

Department of Geriatric Nursing

School of Nursing and Midwifery

North Khorasan University of Medical Sciences, Bojnurd I.R. Iran

\section{Mehran Ghazalibina}

Department of Microbiology

School of Public Health

Tehran University of Medical Sciences, Tehran

I.R. Iran

\section{Shamseddin Mansouri}

Antimicrobial Resistance Research Center

Department of Microbiology, Ghaem Hospital

Mashhad University of Medical Sciences, Mashhad

I.R. Iran
Azad Khaledi*

Infectious Diseases Research Center

Department of Microbiology and Immunology

Faculty of Medicine

Kashan University of Medical Sciences, Kashan

I.R. Iran

Azad Khaledi*

Department of Microbiology and Immunology

Faculty of Medicine

Kashan University of Medical Sciences, Kashan

I.R. Iran

Ehsan Saburi

Bu-Ali Research Institute

Department of Immunogenetics

Mashhad University of Medical Sciences, Mashhad

I.R. Iran

*Corresponding author; email: azadkh99@gmail.com

Received: 13 May 2019

Accepted: 7 October 2019 